\title{
Evaluation of Asteraceae herbal extracts in the management of diabetes and obesity. Contribution of caffeoylquinic acids on the inhibition of digestive enzymes activity and formation of advanced glycation end-products (in vitro)
}

\author{
Vítor Spínola, Paula C. Castilho* \\ CQM - Centro de Química da Madeira, Universidade da Madeira, Campus da Penteada, 9020-105 Funchal, Portugal
}

\section{A R T I C L E I N F O}

\section{Article history:}

Received 6 March 2017

Received in revised form

29 June 2017

Accepted 20 July 2017

Available online 26 July 2017

\section{Keywords:}

Asteraceae plants

Caffeoylquinic acids

Hyperglycaemia

Digestive enzymes inhibition

Advanced glycation end-products

\begin{abstract}
A B S T R A C T
The study was performed to assess, for the first time, the in vitro anti-diabetic potential of ten Asteraceae plant extracts to inhibit the activity of digestive enzymes ( $\alpha$-amylase, $\alpha-, \beta$-glucosidases and lipase) responsible for hydrolysis/digestion of sugar and lipids. Prevention of advanced glycation end-products (AGEs) formation was evaluated in bovine serum albumin/ribose glycation reaction model. The phytochemical profiles and caffeoylquinic acids (CQAs) contents were determined for the methanolic extract of each plant. Analyzed plant extracts exhibited significant inhibitory activity against key digestive enzymes linked to type II diabetes and obesity. A strong inhibition was observed for glucosidases and mild activity towards amylase and lipase (compared to reference compounds). Moreover, some extracts exhibited potent ability to prevent formation of AGEs, implicated in some diabetic complications. Caffeoylquinic acids were dominant in all plant extracts and findings demonstrate that these compounds are the most relevant hypoglycemic and anti-glycation agents. From the obtained results, Argyranthemum pinnatifidum, Helichrysum melaleucum, and Phagnalon lowei are good candidates for further development of phyto-pharmaceutical preparations as complementary therapy for diabetes and obesity control.
\end{abstract}

ㄷ) 2017 Elsevier Ltd. All rights reserved.

\section{Introduction}

Type II diabetes (T2D) is a chronic metabolic disease characterized by hyperglycemia, due to inefficient insulin secretion (de la Garza et al., 2013; Orhan et al., 2014). Prolonged hyperglycemia can induce non-enzymatic glycosylation of proteins, lipids and nucleic acids that lead to the development of diabetic complications (Bains and Gugliucci, 2017; Tsuji-Naito et al., 2009). One practical target for decreasing post-prandial hyperglycemia is to prevent the absorption of carbohydrates after food intake (Nurul et al., 2013). Digestive enzymes such as glucosidases, amylase and lipase control

Abbreviations: AGEs, advanced glycations end-products; AMG, aminoguanidine; ANOVA, analysis of variance; BSA, bovine serum albumin; CQA, caffeoylquinic acid; DAD, diode-array detector; DE, dry extract; 1-DNJ, 1-deoxynojirimycin; DP, dry plant; HCAs, hydroxycinnamic acids; HPLC-ESI-MS ${ }^{\mathrm{n}}$, high-performance liquid chromatography with electrospray ionization mass spectrometric detection; MS, mass spectrometry; TIPC, total individual phenolic content.

* Corresponding author. Tel.: +3651 291705102.

E-mail address: castilho@uma.pt (P.C. Castilho). the breakdown and absorption of glucose and lipids and their precursors in the gastrointestinal tract (Chethan et al., 2014). Several synthetic inhibitors (acarbose, miglitol, voglibose and orlistat) are currently available and seems to be an effective way to control T2D and obesity (Podsędek et al., 2014). However, these pharmaceutical drugs can cause side/adverse effects (abdominal pain, flatulence, diarrhea, hepatotoxicity) due to the increase of undigested starch and lipids levels in the colon (de la Garza et al., 2013; Nurul et al., 2013). As a result, the attention of the scientific community has been directed towards the search for novel effective agents isolated from medicinal or edible plants (Chethan et al., 2014; Orhan et al., 2014). The natural active phytochemicals present in some plants (polyphenols, terpenoids, saponins, polysaccharides, steroids) can provide an alternative strategy with relatively lower cost (Arulselvan et al., 2014; El-Abhar and Schaalan, 2014). Moreover, the use plant extracts as a combination therapy can contribute to reduce the intake of pharmaceutical drugs and, consequently, reduce side effects (Ranilla et al., 2010).

Within the 165 endemic species of Madeira archipelago, Helichrysum devium Johns., Helichrysum melaleucum Rchb. Ex Holl, 
Helichrysum obconicum DC., and Helichrysum monizii Lowe (Asteraceae) herbs stand out for their use in treatment of respiratory and gastro-intestinal diseases: (Rivera and Obón, 1995). Other Asteraceae species like Andryala glandulosa ssp. varia (Lowe ex DC.) R. Fern, Artemisia argentea L'Herit and Cyanara cardunculus L. (var. ferocissima) Lowe have also been applied for other medicinal purposes (Rivera and Obón, 1995). Previous studies developed by our work group (Gouveia et al., 2013; Gouveia and Castilho, 2012a, 2012b, 2011a, 2011b, 2010, 2009) have shown that caffeoylquinic acids (CQAs) are the dominant polyphenols in these species. This class of compounds is particularly abundant in Asteraceae plants (Gouveia and Castilho, 2012c) and is reported to possess beneficial hypoglycemic, hypolipidemic and hepatoprotective properties (Bahadoran et al., 2013; Hanhineva et al., 2010; Meng et al., 2013; Narita et al., 2012).

Although the antioxidant activities of some of these plants have been published (Gouveia et al., 2013; Gouveia and Castilho, 2012b, 2011b) there is no information about their potential on the management of diabetes and obesity. Thus, the focus of this study was to evaluate their inhibitory activities on key digestive enzymes ( $\alpha$ amylase, $\alpha-, \beta$-glucosidases and lipase) and on the formation of advanced glycation end-products (AGEs) using in vitro models. Moreover, this is the first report on the phytochemical composition, hypoglycemic and anti-glycation effects of other three Asteraceae species (Calendula maderensis DC, Argyranthemum pinnatifidum Lowe var. pinnatifidum and Phagnalon lowei DC). These new data may stimulate cultivation and induce utilization of targeted plant species towards the development of phytho-pharmaceuticals.

\section{Results and discussion}

The phytochemical profiles of $A$. pinnatifidum, C. maderensis and $P$. lowei are here described for the first time. These profiles are shown in supplementary material (Supplementary Fig. 1 and Table 1). The phenolic composition of remaining samples has been established previously by our work group (Gouveia et al., 2013; Gouveia and Castilho, 2012a, 2012b, 2011a, 2011b, 2010, 2009). Since CQAs contributed to the major components of analyzed plant species (Fig. 1), their quantification was further determined.

\subsection{Quantification of caffeoylquinic acids}

The content of CQAs varied significantly between targeted species (Table 2). P. lowei showed the highest total amount of CQAs, followed by $H$. melaleucum, A. pinnatifidum and $H$. monizii; A. glandulosa presented the lowest concentrations $(p<0.05)$. Additionally, differences $(p<0.05)$ were found for $H$. melaleucum collected at different seasons/areas. It is known that a number of factors can affect the phenolic composition of plants (environmental and soil conditions, harvest time, genetic variability) (Dalar and Konczak, 2014; Podsędek et al., 2014). 1,5-O-diCQA and 5-OCQA were found to be major compounds in analyzed plants (Table 2). The first component was dominant in most Helichrysum species, A. pinnatifidum (flowers) and P. lowei. 5-O-CQA was present in highest amounts on $A$. argentea, $A$. pinnatifidum (leaves) and C. maderensis. For $\mathrm{H}$. obconicum and $A$. glandulosa samples, 3,5-OdiCQA was the dominant compound, while for $C$. cardunculus was 4,5-diCQA. 1,3-O-diCQA and 3,4-O-diCQA were the isomers present in lower amounts. 3,4,5-O-triCQA was determined only in

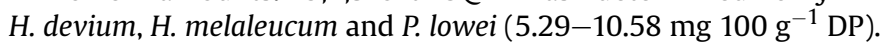

\subsection{In vitro anti-diabetic assays}

Inhibition of digestive enzymes activity by polyphenols is a reasonable approach to control hyperglycaemia and calorie intake in T2D patients, through reduction of sugar and fatty acids absorption from the intestine (Chethan et al., 2014; Podsędek et al., 2014). To this end, medicinal herb extracts have been as complementary therapy of diabetic and obesity complications (Arulselvan et al., 2014; El-Abhar and Schaalan, 2014).

All analyzed plants showed different effects on the assayed digestive enzymes, as shown in Table 3: A. pinnatifidum showed the strongest inhibition of yeast $\alpha$-glucosidase activity $(p<0.05)$ and $C$. maderensis the lowest. Six out of ten plant extracts showed higher inhibitory effect than standard anti-diabetic drug acarbose ( $<2.06 \mathrm{mg} \mathrm{mL}^{-1} \mathrm{DE}$ ) (Table 3). Leaves of A. pinnatifidum were more effective than 1-deoxynojirimycin (1-DNJ), a known glucosidases inhibitor isolated from mulberry leaves (Morus spp. L.).

$\alpha$-Glucosidase isolated from yeast has been widely used for pharmacological screenings (Yin et al., 2014). However, $\alpha$-glucosidase from rat closely mimics the human system and, therefore, provides a better model to validate results (Babu et al., 2004). So, in this work, both glucosidases were tested to verify and compare any differences in the enzyme inhibitory action of plants extracts. It was observed that the $\mathrm{IC}_{50}$ values of analyzed extracts were higher than in the microbial version of the enzyme (Table 3 ). A correlation of 0.901 at $p<0.05$ was obtained from results of both $\alpha$-glucosidase models. By contrast, acarbose and 1-DNJ displayed superior inhibitory activity on rat $\alpha$-glucosidase (about 17 and 65 times higher, respectively). Previous works (Shai et al., 2011; Tadera et al., 2006) have reported a higher effectiveness of acarbose over mammalian enzyme than over the yeast counterpart. Interestingly, the action of the three CQA derivatives on the inhibition of the activity of both enzymes is of the same order of magnitude and, although weaker than acarbose, much superior to the extracts. Overall, this study confirm that inhibition of yeast $\alpha$-glucosidase does not translate into comparable inhibition of the mammalian enzyme. These findings are in agreement with previous works (Babu et al., 2004; Shai et al., 2011; Tadera et al., 2006) that observed a decrease on the efficiency of extracts and flavonoids on rat $\alpha$-glucosidase when compared to the microbial equivalent. The discrepancy is due to the structural differences of the catalytic regions responsible for molecular recognition in the binding site of the enzymes (Shai et al., 2011). Hence, most yeast $\alpha$-glucosidase inhibitors do not show activity on the mammalian equivalent (Kimura et al., 2004). $\alpha$-Glucosidases are widely distributed in microorganisms, plants and animals and the catalytic region is known to differ greatly depending on their origin (Oki et al., 1999). By analysis of the amino acid sequences containing the catalytic sites, these enzymes are generally classified into two groups: family I and family II. The first family consists of bacterial, yeast and insect enzymes and are composed of four catalytic regions; while family II (mold, plants and mammalian) have two catalytic sites responsible for the enzyme reaction (Kimura et al., 2004). These differences justify the divergent values obtained in this work (Table 3). Our findings support the use of mammalian $\alpha$-glucosidase as a preferable model to investigate new antihyperglycemic agents. Conduritol B epoxide, a known $\beta$-glucosidase inhibitor, was more active than A. glandulosa, C. cardunculus and C. maderensis $(p<0.05)$ but all the other plant extracts performed better than the reference. $P$. lowei, $H$. obconicum, $H$. melaleucum and $A$. pinnatifidum showed the highest $\beta$-glucosidase inhibition $(p<0.05)$, while $C$. maderensis was the less active species. 1-DNJ showed the best inhibitory activity among tested samples $(p<0.05)$. Apart from $H$. obconicum, these very active species are also those with the highest contents in CQAs, mainly 5-O-CQA and 1,5-di-O-CQA, which indicates these two compounds as the most relevant to the observed activity. However, $\mathrm{H}$. obconicum is unique on having 3,5-di-O-CQA as main component on a relatively low CQA contents. This points out to a very high activity of this molecule, in fact, when individually 


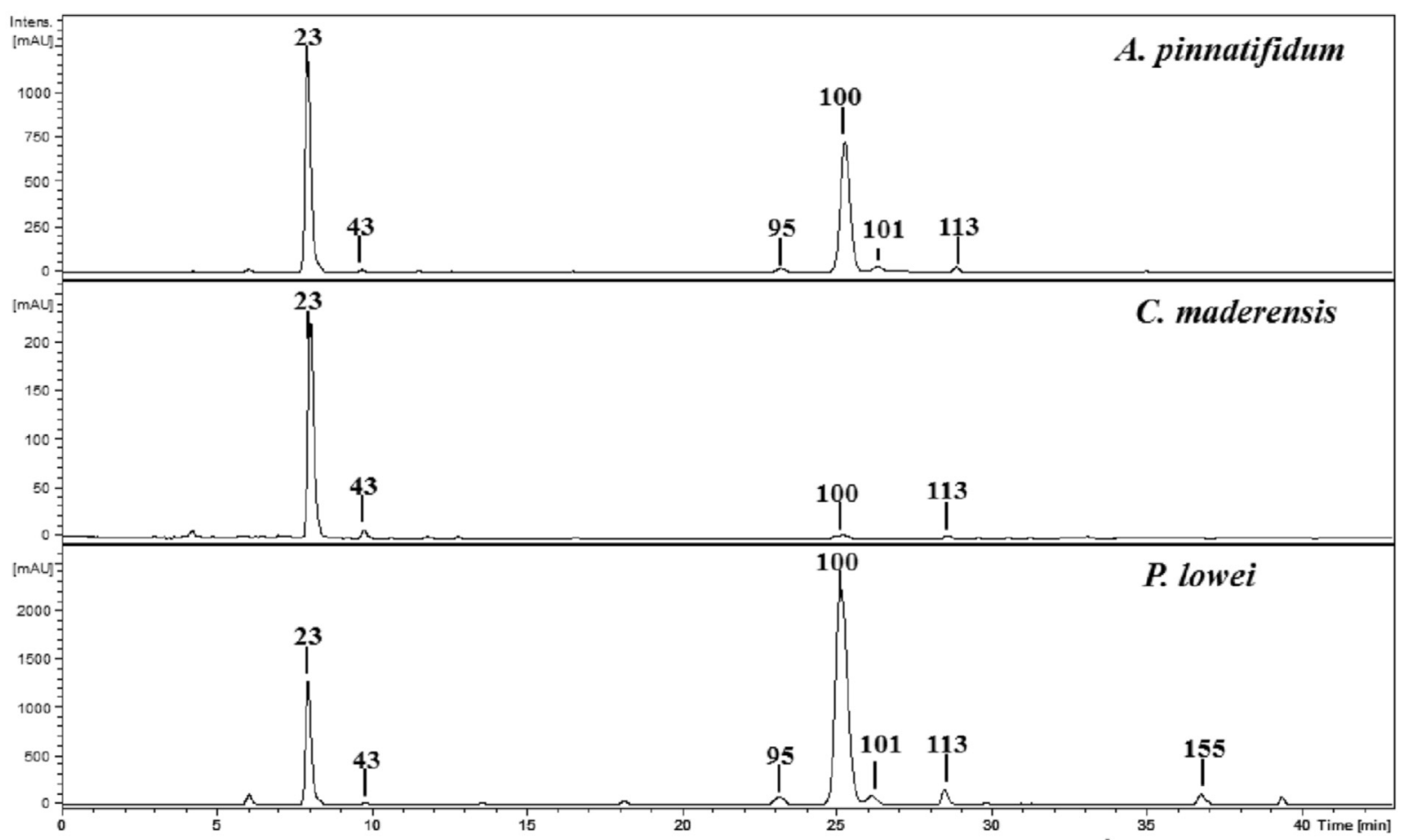

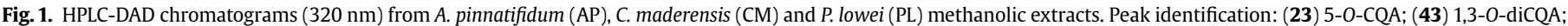
(95) 3,4-O-diCQA; (100) 1,5-O-diCQA; (101) 3,5-O-diCQA; (113) 4,5-O-diCQA; and (155) 3,4,5-O-triCQA.

evaluated, 3,5-di-O-CQA was the most active among tested CQA derivatives $(p<0.05)$ (Table 3$)$.

These experiments have shown that tested plants have a moderate $\alpha$-amylase inhibitory capacity (Table 3 ). All samples presented higher $\mathrm{IC}_{50}$ values than acarbose $\left(0.02 \mathrm{mg} \mathrm{mL}^{-1}\right)(p<0.05)$. A. pinnatifidum, $A$. argentea, $H$. devium and $H$. melaleucum were the most effective inhibitors of this enzyme $\left(<2 \mathrm{mg} \mathrm{mL}^{-1} \mathrm{DE}\right)$, while C. maderensis and C. cardunculus showed the highest $\mathrm{IC}_{50}$ values.

For the lipase assay (Table 3), plant extracts showed weaker inhibition effect than commercial drug orlistat $(p<0.05)$. P. lowei showed the stronger inhibition, while $C$. maderensis showed the lowest effect $(p<0.05)$. Again, CQA derivatives presented activities similar to the commercially available drug.

Similar plants have been analyzed for their inhibitory activity by other authors in previous works: marigold (Calendula officinalis) extracts were less effective towards $\alpha$-amylase and lipase than acarbose (Olennikov and Kashchenko, 2014) and orlistat (Hernández-Saavedra et al., 2016), respectively. Artemisia apiaceae and Artemisia cappilaris exhibited higher inhibition capacity than acarbose for yeast $\alpha$-glucosidase assay (Nurul et al., 2013), while Artemisia vulgaris was a more relevant inhibitor of yeast $\alpha$-glucosidase than of $\alpha$-amylase (Chethan et al., 2014). Helichrysum italicum showed higher inhibitory activities against yeast $\alpha$-glucosidase and $\alpha$-amylase $\left(0.19\right.$ and $0.83 \mathrm{mg} \mathrm{mL}^{-1} \mathrm{DE}$, respectively) (de la Garza et al., 2013) than tested extracts. It should be observed that high $\alpha$-glucosidase but lower $\alpha$-amylase inhibitory activity is recommended for an efficient drug, in order to prevent bacterial fermentation of excessive undigested carbohydrates in the colon, which results in undesirable side-effects (flatulence and diarrhea) (de la Garza et al., 2013; Nurul et al., 2013).

Globe artichoke (Cynara scolymus) had a weak inhibitory effects at $100 \mu \mathrm{g} \mathrm{mL}^{-1}$ (about 20\%) towards $\alpha$-glucosidase from Bacillus stearothermophilus and lipase when compared to positive controls (acarbose and orlistat, respectively) (Villiger et al., 2015). Similar to present work, common chicory (Cichorium intybus) and sowthistle (Sonchus subsp. asper and oleraceus) are reported to act as strong $\alpha$ glucosidase inhibitors, but possess a weak $\alpha$-amylase and lipase inhibition activities (Conforti et al., 2012; Dalar and Konczak, 2014). Higher inhibitions were found for $H$. graveolens and $H$. plicatum ssp. plicatum $\left(\mathrm{IC}_{50}=0.71\right.$ and $0.86 \mathrm{mg} \mathrm{mL}^{-1}$, respectively) towards $\alpha$ glucosidase from B. stearothermophilus (Orhan et al., 2014).

Plants/herbs from Asteraceae family have been used in folk medicine for a long time (Chethan et al., 2014; Hernández-Saavedra et al., 2016; Nurul et al., 2013; Olennikov and Kashchenko, 2014; Villiger et al., 2015). Their beneficial properties are mainly attributed to their high CQAs contents. We initially observed that analyzed species with the highest CQAs content presented showed the most efficient inhibitory activities. Considering that 5-O-CQA, 1,5 and 3,5-di-O-CQAs were found in high amounts in the analyzed extracts, the inhibitory potential of these compounds were further evaluated in detail. 5-O-CQA (the main compound in 6 of the 10 analyzed extracts) was found to be an effective inhibitor of targeted enzymes (Table 3 ), with lower $\mathrm{IC}_{50}$ values than positive controls in yeast $\alpha$-glucosidase, $\beta$-glucosidase and lipase assays $(p<0.05)$. In case of rat $\alpha$-glucosidase, its potency was only inferior to 1 -DNJ and acarbose. Additionally, it was more effective than analyzed extracts and other CQAs towards $\alpha$-amylase (Table 3 ). In agreement, extracts with the highest 5-O-CQA contents exhibited stronger inhibitory activities (Tables 2 and 3 ). In case of di-CQA isomers, their potent inhibitory activity towards digestive enzymes was also noted (Table 3).

Previously (Bahadoran et al., 2013; Hanhineva et al., 2010; Meng et al., 2013; Narita et al., 2012), CQAs have been reported as potent inhibitors of digestive enzymes. 5-O-CQA action is known to resembled that of commercially available drugs such as acarbose, miglitol, and voglibose, which are widely used in control of hyperglycaemia (Meng et al., 2013). In the present study, 5-O-CQA was more effective than acarbose towards $\alpha$-glucosidase (Table 3 ). 
Inhibition of $\alpha$-glucosidase by CQAs appears to be non-competitive, suggesting binding to, or interaction with, other sites than the recognized active site of the enzyme (Ishikawa et al., 2007). The esterification of caffeic acid with quinic acid seems to increase its ability to inhibit carbohydrate digestive enzymes (Chen et al., 2014; Funke and Melzig, 2005; Ishikawa et al., 2007; Narita and Inouye, 2009). Other studies (Meng et al., 2013; Narita et al., 2012; Narita and Inouye, 2009; Worsztynowicz et al., 2014) have also reported the strong in vitro inhibitory effect of CQAs and its derivatives on $\alpha$ amylase and pancreatic lipase activities. In this sense, 5-O-CQA can be considered as one of the main active anti-hyperglycemic agents of targeted plants; Nevertheless, other polyphenols present in the extracts, namely other CQAs derivatives, might also contribute for the obtained results. The present data (Table 3 ) demonstrate that 5$O-C Q A, 1,5-$ and 3,5-di-O-CQAs are the major hypoglycemic agents present in extracts of analyzed plants.

Glycation is a non-enzymatic reaction between the carbonyl group of reducing sugars and a free amino group of proteins that result to the formation of AGEs (Bains and Gugliucci, 2017; Gugliucci et al., 2009). Formation of AGEs induced by hyperglycemia is involved in the pathogenesis of atherosclerosis, nephropathies and retinopathy (Li et al., 2014; Séro et al., 2013). As such, inhibition of AGE formation represents another therapeutic target for the prevention and treatment of diabetic complications (Chinchansure et al., 2015). The analyzed plant extracts showed good in vitro inhibitory potential to glycation of BSA (Table 3). Leaves of $A$. pinnafitidum and $P$. lowei and $H$. melaleucum showed the highest anti-glycation activities $\left(\leq 1.92 \mathrm{mg} \mathrm{mL}^{-1} \mathrm{DE}\right)(p<0.05)$. All tested samples showed a lower $\mathrm{IC}_{50}$ values than AMG, an investigational AGEs inhibitor drug. The same behavior was documented before for Chrysanthemum species (Asteraceae) extracts (Tsuji-Naito et al., 2009). This is might be due to the fact that AMG is not effective in the early stage of protein glycation since it acts as a carbonyl scavenger (Chinchansure et al., 2015). Quercetin displayed the best inhibitory activity among tested samples $(p<0.05)$. This is in agreement with previous publications (Chinchansure et al., 2015; Li et al., 2014; Séro et al., 2013) that report quercetin and compounds with quercetin-like structure (flavonols) more effective than other flavonoids and AMG towards formation of AGEs.

5-O-CQA revealed a strong inhibitory effect, superior to AMG and comparable to quercetin $(p<0.05)$. 1,5- and 3,5-di-O-CQAs were also active compounds (Table 3 ). Based on these findings, CQAs may be considered the main factors responsible for the prevention of AGEs formation in the analyzed plant extracts (Table 3). It is know that, 5-O-CQA possess potent anti-glycation effects (Chinchansure et al., 2015). In fact, caffeic acid and 5-O-CQA isolated from $I$. paraguariensis are the main inhibitors of AGES formation and have also shown higher anti-glycation activities than that of AMG (Bains and Gugliucci, 2017; Gugliucci et al., 2009). In another study, extracts of $C$. morifolium exhibited comparable anti- glycation activity to $A$. pinnatifidum and $P$. lowei $\left(\right.$ IC50 $\left.=1.3 \mathrm{mg} \mathrm{mL}^{-1}\right)$, while $C$. indicum showed lower effects $\left(\mathrm{IC}_{50}=10.1 \mathrm{mg} \mathrm{mL}^{-1}\right.$ ) (Tsuji-Naito et al., 2009). Again, CQAs are the main active principles of above plants against glycation of BSA. These data support other beneficial effects of targeted extracts in the control of $\mathrm{T} 2 \mathrm{D}$, besides lowering hyperglycemia throughout inhibition of digestive enzymes.

\section{Experimental}

\subsection{Chemicals and reagents}

All reagents and standards were of analytical reagent (AR) grade unless stated otherwise. Methanol (99.9\%) was obtained from Fluka (Lisbon, Portugal). Sodium carbonate (100\%), $\alpha$-glucosidase from Saccharomyces cerevisiae (type I), intestinal acetone powder from rat source of $\alpha$-glucosidase, $\beta$-glucosidase from almonds, $\alpha$-amylase from porcine pancreas (type VI-B), lipase (type II; from porcine pancreas), $p$-nitrophenyl- $\alpha$-D-glucopyranoside ( $\alpha$-pNPG), $p$-nitrophenyl- $\beta$-D-glucopyranoside ( $\beta$-pNPG), $p$-nitrophenyl butyrate $(p N P B)$, bovine serum albumin (BSA, $\geq 98 \%$ ), D-(-)-ribose ( $\geq 99 \%$ ), aminoguanidine hydrochloride (AMG, $\geq 98 \%$ ), conduritol B epoxide ( $\geq 95 \%$ ), acarbose, orlistat and formic acid (98\%) were purchased from Sigma-Aldrich (St. Louis, MO, USA). 5-O-cafeoylquinic acid (>95\%), 1,5-; 1,3-; 3,4-; 4,5-di-O-caffeoylquinic acids (>98\%), 3,4,5$O$-tricaffeoylquinic acid (>98\%) and 1-deoxynojirimycin (95-99\%; 1-DNJ) were purchased from Biopurify Phytochemicals LTD (Chengdu, China). Ethylenediaminetetraacetic acid (EDTA, >99\%) and sodium azide (>99\%) were obtained from Merck (Darmstadt, Germany). LC-MS grade acetonitrile $\left(\mathrm{CH}_{3} \mathrm{CN}\right.$, 99\%) (LabScan; Dublin, Ireland) and ultrapure (UP) water (Milli-Q Waters purification system; Millipore; Milford, MA, USA) were used for the HPLC-MS analyses.

\subsection{Sample preparation and extraction of phenolic compounds}

Plant material was collected in different locations of Madeira archipelago between May and December 2014 and identified by specialists from Madeira Botanical Garden (Funchal, Madeira). Vouchers were deposited at Madeira Botanical Garden Herbarium (for a more detailed description see Table 1 ). Leaves were separated from flowers, lyophilized to dryness (Alpha 1-2 LD plus freeze dryer, CHRIST), ground to powder in a mechanic grinder, and stored at $-20{ }^{\circ} \mathrm{C}$. Phenolic extraction followed a previous procedure (Gouveia and Castilho, 2011b). The resulting extracts were stored at $4{ }^{\circ} \mathrm{C}$ until further analysis.

\subsection{HPLC analysis}

The HPLC-ESI-MS ${ }^{\mathrm{n}}$ analysis was performed on a Dionex ultimate

Table 1

Information on botanical name, morphological parts and collection area of targeted Asteraceae plant species endemic from Madeira archipelago.

\begin{tabular}{|c|c|c|c|c|}
\hline Botanical name & Common names & Morphological parts & Collection area & Voucher Number \\
\hline A. glandulosa ssp. var. (L. ex DC.) R. Fern & Bofe de burro & Leaves & Pico Grande, Madeira Island & MADJ13175 \\
\hline A. pinnatifidum L. (var. pinnatifidum) & Estreleira; Malmequer & Leaves; Flowers & Ribeira das Cales, Madeira Island & MADJ13185 \\
\hline A. argentea L'Herit & Losna & Leaves; Flowers & Pico Branco, Porto Santo Island & MADJ13164 \\
\hline C. maderensis DC. & Vaqueira & Leaves; Flowers & São Jorge, Madeira Island & MADJ13165 \\
\hline C. cardunculus L. (var. ferocíssima) & Cardo; Pencas & Total aerial parts & Ponta de São Lourenço, Madeira Island & MADJ13162 \\
\hline H. devium Johns. & Perpétua & Leaves; Flowers & Ponta de São Lourenço, Madeira Island & MADJ13180 \\
\hline \multirow[t]{2}{*}{ H. melaleucum Rchb. Ex Holl } & Perpétua branca & Leaves; Flowers & São Vicente, Madeira Island & MADJ13177 \\
\hline & & Leaves & Ilhéu de Cima, Porto Santo Island & MADJ13192 \\
\hline H. monizii L. & - & Total aerial parts & Funchal, Madeira Island & MADJ13178 \\
\hline H. obconicum DC. & Aipo branco; Murrião & Leaves & Ponta de São Lourenço, Madeira Island & MADJ13179 \\
\hline P. lowei DC. & Erva do Iscas & Leaves & Ilhéu de Cima, Porto Santo Island & MADJ13186 \\
\hline
\end{tabular}


Table 2

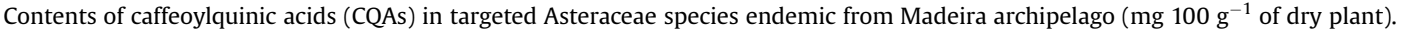

\begin{tabular}{|c|c|c|c|c|c|c|c|c|c|}
\hline Compound & & 5-CQA & 1,3-diCQA & 3,4-diCQA & 1,5-diCQA & 3,5-diCQA & 4,5-diCQA & 3,4,5-triCQA & Total amount \\
\hline \multirow[t]{3}{*}{ A. argentea } & Leaves $^{\mathrm{b}}$ & $358.62 \pm 2.09$ & $4.15 \pm 0.07$ & a & $275.00 \pm 1.04$ & a & $32.90 \pm 0.41$ & N.D. & $670.67 \pm 3.28^{\mathrm{h}}$ \\
\hline & Flowers & $359.51 \pm 1.98$ & $32.48 \pm 0.32$ & a & $269.68 \pm 0.99$ & a & $13.69 \pm 0.09$ & N.D. & $675.36 \pm 4.97^{\mathrm{h}}$ \\
\hline & Leaves $^{\mathrm{b}}$ & $495.50 \pm 3.32$ & $9.81 \pm 0.06$ & a & $323.74 \pm 1.06$ & a & $22.11 \pm 1.01$ & N.D. & $851.16 \pm 3.77^{\mathrm{j}}$ \\
\hline A. glandulosa & Leaves¥ & $22.40 \pm 0.21$ & N.D. & N.D. & N.D. & $50.69 \pm 1.1$ & $3.81 \pm 0.03$ & N.D. & $85.90 \pm 1.3^{\mathrm{a}}$ \\
\hline \multirow[t]{2}{*}{ A. pinnatifidum } & Leaves & $838.48 \pm 2.11$ & $0.84 \pm 0.06$ & $8.65 \pm 0.13$ & $430.22 \pm 1.11$ & $14.38 \pm 0.16$ & $8.77 \pm 0.07$ & N.D. & $1301.34 \pm 2.14^{\mathrm{n}}$ \\
\hline & Flowers & $214.16 \pm 0.89$ & $0.40 \pm 0.01$ & $4.65 \pm 0.07$ & $636.99 \pm 2.50$ & $4.80 \pm 0.06$ & $6.17 \pm 0.05$ & N.D. & $867.17 \pm 0.89^{k}$ \\
\hline C. ferocissima & Total aerial parts & $77.20 \pm 0.54$ & $0.80 \pm 0.03$ & N.D. & $8.4 \pm 0.09$ & $65.80 \pm 0.27$ & $89.24 \pm 0.47$ & N.D. & $241.44 \pm 1.07 \mathrm{e}$ \\
\hline \multirow[t]{2}{*}{ C. maderensis } & Leaves & $191.51 \pm 0.77$ & a & a & $2.03 \pm 0.01$ & a & $1.01 \pm 0.01$ & N.D. & $194.55 \pm 1.07^{c}$ \\
\hline & Flowers & $180.49 \pm 0.64$ & $\mathrm{a}$ & a & $32.23 \pm 0.54$ & a & $2.02 \pm 0.02$ & N.D. & $214.74 \pm 1.32^{\mathrm{d}}$ \\
\hline \multirow[t]{2}{*}{ H. devium } & Leaves $\Phi$ & $35.19 \pm 0.06$ & $2.73 \pm 0.05$ & $\mathrm{a}$ & $125.4 \pm 0.03$ & $0.462 \pm 0.02$ & $17.33 \pm 0.05$ & $5.29 \pm 0.04$ & $186.4 \pm 0.71^{\mathrm{b}}$ \\
\hline & Flowers $\Phi$ & $129.2 \pm 1.20$ & a & $1.89 \pm 0.04$ & $197.3 \pm 0.39$ & $49.92 \pm 0.19$ & $40.58 \pm 0.03$ & ta & $422.6 \pm 1.8^{f}$ \\
\hline \multirow[t]{3}{*}{ H. melaleucum } & Leaves $\Phi$ & $345.0 \pm 1.20$ & $5.86 \pm 0.03$ & N.D. & $915 \pm 1.4$ & $30.61 \pm 1.6$ & $60.44 \pm 0.43$ & $10.58 \pm 0.01$ & $1367.9 \pm 0.64^{\circ}$ \\
\hline & Flowers $\Phi$ & $114.0 \pm 0.47$ & & N.D. & $628.8 \pm 0.11$ & N.D. & $43.12 \pm 0.11$ & $10.15 \pm 0.01$ & $804.03 \pm 0.74^{\mathrm{i}}$ \\
\hline & Leaves $^{\mathrm{c}}$ & $355.99 \pm 2.50$ & $33.68 \pm 0.49$ & N.D. & $687.86 \pm 0.96$ & $29.61 \pm 0.97$ & $12.26 \pm 0.10$ & a & $1119.40 \pm 2.45^{1}$ \\
\hline H. monizii & Total aerial parts $\Phi$ & $375.9 \pm 0.53$ & a & $16.5 \pm 0.05$ & $441.9 \pm 0.58$ & $303.29 \pm 0.61$ & $31.67 \pm 0.06$ & a & $1169.3 \pm 1.8^{\mathrm{m}}$ \\
\hline H. obconicum & Leaves $\Phi$ & $52.19 \pm 0.73$ & $\mathrm{a}$ & $16.99 \pm 0.24$ & $83.09 \pm 2.9$ & $469.5 \pm 0.25$ & $82.53 \pm 0.11$ & a & $604.7 \pm 1.1^{\mathrm{g}}$ \\
\hline P. lowei & Leaves & $575.74 \pm 2.72$ & N.D. & 1 & $1276.32 \pm 12.97$ & $20.16 \pm 0.34$ & $37.27 \pm 0.25$ & $8.45 \pm 0.36$ & $1917.94 \pm 4.33^{p}$ \\
\hline
\end{tabular}

$¥($ Gouveia et al., 2013) $\Phi$ (Gouveia and Castilho, 2012c).

Means in the same column not sharing the same letter are significantly different at $p<0.05$ probability level.

a Compounds present in trace amounts (lower than the LOQ); N.D. - Not detected.

b Samples collected in different time periods (May and December 2014).

c Samples collected in Porto Santo Island.

3000 series instrument (Thermo Scientific Inc.) equipped with a binary pump, an autosampler and a column compartment (kept at $30^{\circ} \mathrm{C}$ ) and coupled with a Bruker Esquire model 6000 ion trap mass spectrometer with an ESI source (Bremen, Germany). Analysis was carried out on a Phenomenex Gemini $\mathrm{C}_{18}$ column $(5 \mu \mathrm{m}$, $250 \times 3.0 \mathrm{~mm}$ i.d.) using the same conditions as previously (Gouveia and Castilho, 2012c). Extract solutions ( $5 \mathrm{mg} \mathrm{mL}^{-1}$ ) were prepared by dissolving the dry extract (DE) in the initial HPLC mobile phase. After filtration through $0.45 \mu \mathrm{m}$ PTFE membrane filters, $5 \mu \mathrm{L}$ was injected.

\subsection{Quantification of caffeoylquinic acids (CQAs)}

For the quantitative analysis, a previously validated HPLC-PDA method was applied (Gouveia and Castilho, 2012c). Identification and quantification were performed by comparison with standards: 5-CQA, 1,3-; 3,4-; 1,5-; 3,5-, 4,5-O-diCQA and 3,4,5-O-triCQA. Six concentrations were used for each calibration curve $\left(R^{2} \geq 0.9991\right)$

Table 3

In vitro inhibitory activities $\left(\mathrm{IC}_{50}\right)$ of targeted plant extracts towards digestive enzymes and BSA glycation.

\begin{tabular}{|c|c|c|c|c|c|c|c|}
\hline \multirow[t]{2}{*}{ Plant Species } & & \multicolumn{2}{|l|}{$\alpha$-Glucosidase } & \multirow[t]{2}{*}{$\beta$-glucosidase } & \multirow[t]{2}{*}{$\alpha$-Amylase } & \multirow[t]{2}{*}{ Lipase } & \multirow[t]{2}{*}{ BSA-glycation } \\
\hline & & Yeast & Rat & & & & \\
\hline \multirow[t]{3}{*}{ A. argentea } & Leaves & $1.36 \pm 0.04^{\mathrm{i}}$ & $2.79 \pm 0.10^{\mathrm{g}}$ & $3.83 \pm 0.10^{g}$ & $1.92 \pm 0.04^{e f}$ & $3.85 \pm 0.05^{\mathrm{ef}}$ & $1.83 \pm 0.10^{f}$ \\
\hline & Flowers & $2.01 \pm 0.06^{\mathrm{k}}$ & $2.90 \pm 0.08^{g}$ & $4.38 \pm 0.14^{\mathrm{i}}$ & $2.48 \pm 0.04^{\mathrm{h}}$ & $4.69 \pm 0.2^{\mathrm{gh}}$ & $2.38 \pm 0.19^{g h}$ \\
\hline & Leaves $^{\mathrm{a}}$ & $1.49 \pm 0.04^{\mathrm{j}}$ & $3.42 \pm 0.17^{\mathrm{i}}$ & $3.96 \pm 0.18^{g h}$ & $1.81 \pm 0.03^{\mathrm{de}}$ & $3.67 \pm 0.08^{\mathrm{e}}$ & $2.16 \pm 0.08^{g}$ \\
\hline A. glandulosa & Leaves & $5.60 \pm 0.11^{\circ}$ & $8.70 \pm 0.42^{\mathrm{k}}$ & $11.07 \pm 0.22^{\mathrm{m}}$ & $7.34 \pm 0.10^{j}$ & $6.39 \pm 0.08^{\mathrm{j}}$ & $5.51 \pm 0.10^{1}$ \\
\hline \multirow[t]{2}{*}{ A. pinnatifidum } & Leaves & $0.57 \pm 0.03^{b}$ & $2.39 \pm 0.14^{\mathrm{g}}$ & $3.07 \pm 0.10^{f}$ & $1.55 \pm 0.04^{c}$ & $3.31 \pm 0.09^{d}$ & $1.22 \pm 0.03^{d}$ \\
\hline & Flowers & $0.81 \pm 0.02^{\mathrm{d}}$ & $2.77 \pm 0.11^{g}$ & $3.25 \pm 0.17^{f}$ & $2.18 \pm 0.05^{\mathrm{g}}$ & $4.31 \pm 0.11^{\mathrm{g}}$ & $1.66 \pm 0.09^{\mathrm{ef}}$ \\
\hline C. cardunculus & Total aerial parts & $4.19 \pm 0.15^{\mathrm{n}}$ & $9.11 \pm 0.34^{1}$ & $9.40 \pm 0.12^{1}$ & $9.09 \pm 0.11^{1}$ & $7.52 \pm 0.13^{\mathrm{k}}$ & $4.26 \pm 0.27^{\mathrm{j}}$ \\
\hline \multirow[t]{2}{*}{ C. maderensis } & Leaves & $5.29 \pm 0.12^{\circ}$ & $10.67 \pm 0.19^{\mathrm{m}}$ & $11.87 \pm 0.11^{\mathrm{n}}$ & $8.57 \pm 0.10^{k}$ & $8.89 \pm 0.16^{1}$ & $6.92 \pm 0.18^{1}$ \\
\hline & Flowers & $6.23 \pm 0.10^{\circ}$ & N.D. & $12.57 \pm 0.30^{\circ}$ & $8.91 \pm 0.09^{1}$ & $9.55 \pm 0.11^{\mathrm{m}}$ & $7.45 \pm 0.43^{\mathrm{m}}$ \\
\hline \multirow[t]{2}{*}{ H. devium } & Leaves & $1.44 \pm 0.03^{\mathrm{j}}$ & $4.00 \pm 0.18^{j}$ & $4.47 \pm 0.07^{\mathrm{i}}$ & $1.85 \pm 0.06^{\mathrm{de}}$ & $4.11 \pm 0.06^{\mathrm{fg}}$ & $2.24 \pm 0.14^{\mathrm{hi}}$ \\
\hline & Flowers & $2.13 \pm 0.04^{1}$ & $3.46 \pm 0.13^{i}$ & $5.17 \pm 0.07^{j}$ & $2.39 \pm 0.03^{h}$ & $5.17 \pm 0.15^{\mathrm{i}}$ & $2.84 \pm 0.20^{\mathrm{i}}$ \\
\hline \multirow[t]{3}{*}{ H. melaleucum } & Leaves & $0.99 \pm 0.03^{f}$ & $3.59 \pm 0.11^{\mathrm{i}}$ & $3.18 \pm 0.16^{f}$ & $1.71 \pm 0.02^{\mathrm{cd}}$ & $4.09 \pm 0.05^{\mathrm{fg}}$ & $1.72 \pm 0.10^{f}$ \\
\hline & Flowers & $1.25 \pm 0.04^{\mathrm{h}}$ & $2.72 \pm 0.08^{g}$ & $4.32 \pm 0.09^{h i}$ & $2.15 \pm 0.05^{g}$ & $4.95 \pm 0.04^{\mathrm{hi}}$ & $2.36 \pm 0.13^{g h}$ \\
\hline & Leaves $^{\mathrm{b}}$ & $1.13 \pm 0.01^{g}$ & $3.07 \pm 0.07^{\mathrm{h}}$ & $2.91 \pm 0.11^{\mathrm{ef}}$ & $1.92 \pm 0.09^{\mathrm{ef}}$ & $3.89 \pm 0.06^{\mathrm{ef}}$ & $1.52 \pm 0.09^{\mathrm{de}}$ \\
\hline H. monizii & Total aerial parts & $2.76 \pm 0.05^{\mathrm{m}}$ & N.D. & N.D. & $4.29 \pm 0.11^{\mathrm{i}}$ & N.D. & N.D. \\
\hline H. obconicum & Leaves & $1.35 \pm 0.02^{\mathrm{i}}$ & $3.30 \pm 0.08^{i}$ & $2.51 \pm 0.08^{\mathrm{de}}$ & $2.48 \pm 0.05^{\mathrm{h}}$ & $4.37 \pm 0.11^{g}$ & $2.49 \pm 0.07^{\mathrm{h}}$ \\
\hline P. lowei & Leaves & $0.90 \pm 0.03^{\mathrm{e}}$ & $2.10 \pm 0.11^{\mathrm{f}}$ & $2.33 \pm 0.06^{\mathrm{d}}$ & $2.07 \pm 0.04^{\mathrm{fg}}$ & $3.05 \pm 0.07^{\mathrm{d}}$ & $1.49 \pm 0.08^{\mathrm{e}}$ \\
\hline $5-O-C Q A$ & - & $0.36 \pm 0.02^{\mathrm{b}}$ & $0.27 \pm 0.02^{c}$ & $0.39 \pm 0.01^{\mathrm{b}}$ & $1.20 \pm 0.04^{\mathrm{b}}$ & $0.31 \pm 0.01^{\mathrm{a}}$ & $0.20 \pm 0.01^{\mathrm{b}}$ \\
\hline 1,5-O-DiCQA & & $0.39 \pm 0.03^{b}$ & $0.35 \pm 0.02^{\mathrm{d}}$ & $0.37 \pm 0.02^{b}$ & $1.69 \pm 0.11^{\mathrm{cd}}$ & $0.61 \pm 0.04^{c}$ & $0.27 \pm 0.02^{c}$ \\
\hline 3,5-O-DiCQA & & $0.30 \pm 0.02^{\mathrm{a}}$ & $0.44 \pm 0.03^{\mathrm{e}}$ & $0.28 \pm 0.02^{\mathrm{a}}$ & $2.69 \pm 0.20^{\mathrm{h}}$ & $0.50 \pm 0.03^{b}$ & $0.31 \pm 0.02^{c}$ \\
\hline Acarbose & - & $2.06 \pm 0.04^{\mathrm{k}}$ & $0.12 \pm 0.01^{\mathrm{b}}$ & - & $0.02 \pm 0.001^{\mathrm{a}}$ & - & - \\
\hline 1-Deoxynojrimycin & - & $0.65 \pm 0.02^{c}$ & $0.01 \pm 0.01^{\mathrm{a}}$ & $0.45 \pm 0.02^{c}$ & - & - & - \\
\hline Conduritol B epoxide & - & - & - & $8.94 \pm 0.19^{k}$ & - & - & - \\
\hline Orlistat & - & - & - & - & - & $0.47 \pm 0.02^{\mathrm{b}}$ & - \\
\hline Aminoguanidine & - & - & - & - & - & - & $9.56 \pm 0.36^{\mathrm{n}}$ \\
\hline Quercetin & - & - & - & - & - & - & $0.11 \pm 0.01^{\mathrm{a}}$ \\
\hline
\end{tabular}

N.D.: not determined (sample was scarce).

Means in the same column not sharing the same letter are significantly different at $p<0.05$ probability level.

a Leaves collected in different time periods (May and December 2014).

b Leaves collected in Porto Santo. 
and the method showed good precision $(<2.78 \%)$ and recoveries ( $>96.24 \%$ ) for all standard compounds. The amount of each compound was expressed as mg per $100 \mathrm{~g}$ of dry plant (DP).

\subsection{In vitro enzyme and glycation inhibition assays}

$\alpha$-Glucosidases (from yeast and rat) and $\alpha$-amylase inhibition assays were carried out as described previously (Podsędek et al., 2014; Spínola et al., 2016). The assay for $\beta$-glucosidase was conducted based on $\alpha$-glucosidase assay. Lipase assay was adapted from a previous report (Kim et al., 2010): $40 \mu \mathrm{L}$ of extract solution (serial dilutions) was mixed with $20 \mu \mathrm{L}$ of substrate solution (10 mM of $p$-NPB) and $40 \mu \mathrm{L}$ of enzyme $\left(2.5 \mathrm{mg} \mathrm{mL}^{-1}\right.$ in $0.1 \mathrm{M}$ phosphate buffer, $\mathrm{pH} 8.0$ ). After incubation $\left(20 \mathrm{~min} ; 37^{\circ} \mathrm{C}\right)$ absorbance was read at 405 .

Non-enzymatic glycation of BSA was measured with adaptations from a published protocol (Séro et al., 2013): $50 \mu \mathrm{L}$ of BSA solution (10 mg mL $\mathrm{m}^{-1}$ ), $80 \mu \mathrm{L}$ of $0.1 \mathrm{M}$ phosphate buffer (containing $3 \mathrm{mM}$ sodium azide, $\mathrm{pH} 7.4), 50 \mu \mathrm{L}$ of ribose solution $(0.5 \mathrm{M})$ and $20 \mu \mathrm{L}$ of sample (serial dilutions) were added to each plate. Plates were incubated for $24 \mathrm{~h}$ at $37{ }^{\circ} \mathrm{C}$ and analyzed at an excitation wavelength of $355 \mathrm{~nm}$ and emission wavelength of $460 \mathrm{~nm}$. All assays were conducted in a microtiter reader (Victor ${ }^{3}$, Perkin-Elmer). Acarbose, orlistat, conduritol B epoxide, 1-DNJ, quercetin and AMG were used as positive controls and the $\mathrm{IC}_{50}$ values $\left(\mathrm{mg} \mathrm{mL}^{-1}\right)$ were determined from the least-squares regression line of the logarithmic concentrations plotted against percentage inhibition.

\subsection{Statistical analysis}

The mean values were calculated based on at least three independent replicates $(n=3)$ and results are presented as means \pm standard deviations. Statistical analysis was carried out using one-way analysis of variance (ANOVA) followed by Tukey's post hoc test using SPSS for Windows, IBM SPSS Statistics 20 (SPSS, Inc., USA) to assess differences between samples. A value of $p<0.05$ was considered statistically significant.

\section{Conclusion}

A. pinnatifidum, $H$. melaleucum, and $P$. lowei exhibited the highest inhibitions of key digestive enzymes, suggesting their potential application on regulating glucose and lipids digestion. Targeted plants showed also effective anti-glycation activities, demonstrating another efficient role in delay or prevention of diabetic complications. Caffeoylquinic acids, in particular 5-O-CQA, 1,5- and 3,5-di-O-CQA contribute as the most active principles for the reported in vitro anti-diabetic activities. Nevertheless, the involvement of other compounds, namely other diCQAs, cannot be ruled out since synergistic effects could potentiate or reduce the inhibitory activities. As a follow-up investigation, we intent to isolate and study their individual biological properties as well. Additional in vivo experiments are also required to confirm the biological relevance of analyzed extracts. Overall, the obtained data are helpful for further research and development of these plants in the field of pharmaceutical industries.

\section{Acknowledgments}

The authors are grateful to Francisco Fernandes and José Carvalho from Madeira Botanical Garden and to Funchal Ecological Park for the supply and identification of plant material. V. Spínola is grateful to Fundação para a Ciência e a Tecnologia (FCT, Portugal) for a Ph.D. grant SFRH/BD/84672/2012. This research was supported by FCT with funds from the Portuguese Government (Project PEst-OE/
QUI/UI0674/2013) and the Portuguese National Mass Spectrometry Network (Contract RNEMREDE/1508/REM/2005). Funding through the project M1420-01-0145-FEDER-000005 - Centro de Química da Madeira - CQM+ (Madeira 14-20) is also acknowledged.

\section{Appendix A. Supplementary data}

Supplementary data related to this article can be found at http:// dx.doi.org/10.1016/j.phytochem.2017.07.006.

\section{References}

Arulselvan, P., Ghofar, H.A.A., Karthivashan, G., Halim, M.F.A., Ghafar, M.S.A. Fakurazi, S., 2014. Antidiabetic therapeutics from natural source: a systematic review. Biomed. Prev. Nutr. 4, 607-617.

Babu, K.S., Tiwari, A.K., Srinivas, P.V., Ali, A.Z., Raju, B.C., Rao, J.M., 2004. Yeast and mammalian $\alpha$-glucosidase inhibitory constituents from Himalayan rhubarb Rheum emodi Wall.ex Meisson. Bioorg. Med. Chem. Lett. 14, 3841-3845.

Bahadoran, Z., Mirmiran, P., Azizi, F., 2013. Dietary polyphenols as potential nutraceuticals in management of diabetes: a review. J. Diabetes Metab. Disord. 12

Bains, Y., Gugliucci, A., 2017. Ilex paraguariensis and its main component chlorogenic acid inhibit fructose formation of advanced glycation endproducts with amino acids at conditions compatible with those in the digestive system. Fitoterapia 117, 6-10.

Chen, J., Mangelinckx, S., Ma, L., Wang, Z., Li, W., De Kimpe, N., 2014. Caffeoylquinic acid derivatives isolated from the aerial parts of Gynura divaricata and their yeast $\alpha$-glucosidase and PTP1B inhibitory activity. Fitoterapia 99, 1-6.

Chethan, J., Kumar, P.M.P., Prakash, H.S., 2014. Antidiabetic and antihypertensive potential of selected Asteraceae plant species. Am. J. Adv. Drug Deliv. 2, 355-363.

Chinchansure, A.A., Korwar, A.M., Kulkarni, M.J., Joshi, S.P., 2015. Recent development of plant products with anti-glycation activity: a review. RSC Adv. 5, 31113-31138.

Conforti, F., Perri, V., Menichini, F., Marrelli, M., Uzunov, D., Statti, G.A., Menichini, F. 2012. Wild Mediterranean dietary plants as inhibitors of pancreatic lipase. Phytother. Res. 26, 600-604.

Dalar, A., Konczak, I., 2014. Cichorium intybus from eastern Anatolia: phenolic composition, antioxidant and enzyme inhibitory activities. Ind. Crops Prod. 60, 79-85.

de la Garza, A.L., Etxeberria, U., Lostao, M.P., San Román, B., Barrenetxe, J. Martínez, J.A., Milagro, F.I., 2013. Helichrysum and grapefruit extracts inhibit carbohydrate digestion and absorption, improving postprandial glucose levels and hyperinsulinemia in rats. J. Agric. Food Chem. 61, 12012-12019.

El-Abhar, H.S., Schaalan, M.F., 2014. Phytotherapy in diabetes: review on potential mechanistic perspectives. World J. Diabetes 5, 176-197.

Funke, I., Melzig, M.F., 2005. Effect of different phenolic compounds on $\alpha$-amylase activity: screening by microplate-reader based kinetic assay. Pharmazie 60, 796-797.

Gouveia, S.C., Castilho, P.C., 2012a. Helichrysum monizii Lowe: phenolic composition and antioxidant potential. Phytochem. Anal. 23, 72-83.

Gouveia, S.C., Castilho, P.C., 2012b. Phenolic composition and antioxidant capacity of cultivated artichoke, Madeira cardoon and artichoke-based dietary supplements. Food Res. Int. 48, 712-724.

Gouveia, S.C., Castilho, P.C., 2012c. Validation of a HPLC-DAD-ESI/MSn method for caffeoylquinic acids separation, quantification and identification in medicinal Helichrysum species from Macaronesia. Food Res. Int. 45, 362-368.

Gouveia, S.C., Castilho, P.C., 2011a. Characterisation of phenolic acid derivatives and flavonoids from different morphological parts of Helichrysum obconicum by a RP-HPLC-DAD-(-)-ESI-MS ${ }^{\mathrm{n}}$ method. Food Chem. 129, 333-344.

Gouveia, S.C., Castilho, P.C., 2011b. Antioxidant potential of Artemisia argentea L'Hér alcoholic extract and its relation with the phenolic composition. Food Res. Int 44, 1620-1631.

Gouveia, S.C., Castilho, P.C. 2010. Characterization of phenolic compounds in Helichrysum melaleucum by high-performance liquid chromatography with on-line ultraviolet and mass spectrometry detection. Rapid Commun. Mass Spectrom. 24, 1851-1868.

Gouveia, S.C., Castilho, P.C., 2009. Analysis of phenolic compounds from different morphological parts of Helichrysum devium by liquid chromatography with online UV and electrospray ionization mass spectrometric detection. Rapid Commun. Mass Spectrom. 23, 3939-3953.

Gouveia, S.C., Gonçalves, J., Castilho, P.C., 2013. Characterization of phenolic compounds and antioxidant activity of ethanolic extracts from flowers of Andryala glandulosa ssp. varia (Lowe ex DC.) R.Fern., an endemic species of Macaronesia region. Ind. Crops Prod. 42, 573-582.

Gugliucci, A., Bastos, D.H.M., Schulze, J., Souza, M.F.F., 2009. Caffeic and chlorogenic acids in Ilex paraguariensis extracts are the main inhibitors of AGE generation by methylglyoxal in model proteins. Fitoterapia 80, 339-344.

Hanhineva, K., Törrönen, R., Bondia-Pons, I., Pekkinen, J., Kolehmainen, M., Mykkänen, H., Poutanen, K., 2010. Impact of dietary polyphenols on carbohydrate metabolism. Int. J. Mol. Sci. 11, 1365-1402. 
Hernández-Saavedra, D., Pérez-Ramírez, I.F., Ramos-Gómez, M., Mendoza-Díaz, S., Loarca-Piña, G., Reynoso-Camacho, R., 2016. Phytochemical characterization and effect of Calendula officinalis, Hypericum perforatum, and Salvia officinalis infusions on obesity- associated cardiovascular risk. Med. Chem. Res. 25, 163-172.

Ishikawa, A., Yamashita, H., Hiemori, M., Inagaki, E., Kimoto, M., Okamoto, M., Tsuji, H., Memon, A.N., Mohammadio, A., Natori, Y., 2007. Characterization of inhibitors of postprandial hyperglycemia from the leaves of Nerium indicum. J. Nutr. Sci. Vitaminol. 53, 166-173.

Kim, Y.S., Lee, Y.M., Kim, H., Kim, J., Jang, D.S., Kim, J.H., Kim, J.S., 2010. Anti-obesity effect of Morus bombycis root extract: anti-lipase activity and lipolytic effect. J. Ethnopharmacol. 130, 621-624.

Kimura, A., Lee, J.H., Lee, I.S., Lee, H.S., Park, K.H., Chiba, S., Kim, D., 2004. Two potent competitive inhibitors discriminating alpha-glucosidase family I from family II. Carbohydr. Res. 339, 1035-1040.

Li, X., Zheng, T., Sang, S., Lv, L., 2014. Quercetin inhibits advanced glycation end product formation by trapping methylglyoxal and glyoxal. J. Agric. Food Chem. 62, 12152-12158.

Meng, S., Cao, J., Feng, Q., Peng, J., Hu, Y., 2013. Roles of chlorogenic acid on regulating glucose and lipids metabolism: a review. Evid.-Based Complement. Altern. Med. Article ID 801457.

Narita, Y., Inouye, K., 2009. Kinetic Analysis and mechanism on the inhibition of chlorogenic acid and its components against porcine pancreas $\alpha$-amylase isozymes I and II. J. Agric. Food Chem. 57, 9218-9225.

Narita, Y., Iwai, K., Fukunaga, T., Nakagiri, O., 2012. Inhibitory activity of chlorogenic acids in decaffeinated green coffee beans against porcine pancreas lipase and effect of a decaffeinated green coffee bean extract on an emulsion of olive oil Biosci. Biotechnol. Biochem. 76, 2329-2331.

Nurul, I., Jung, H.A., Sohn, H.S., Kim, H.M., Choi, J.S., 2013. Potent $\alpha$-glucosidase and protein tyrosine phosphatase 1B inhibitors from Artemisia capillaris. Arch. Pharm. Res. 36, 542-552.

Oki, T., Matsui, T., Osajima, Y., 1999. Inhibitory effect of alpha-glucosidase inhibitors varies according to its origin. J. Agric. Food Chem. 47, 550-553.

Olennikov, D.N., Kashchenko, N.I., 2014. Componential profile and amylase inhibiting activity of phenolic compounds from Calendula officinalis L. leaves. Sci. World J. 654193, 9 .
Orhan, N., Hoçbaç, S., Orhan, D.D., Asian, M., Ergun, F., 2014. Enzyme inhibitory and radical scavenging effects of some antidiabetic plants of Turkey. Iran. J. Basic Med. Sci. 17, 426-432.

Podsędek, A., Majewska, I., Redzynia, M., Sosnowska, D., Koziołkiewicz, M., 2014. In vitro inhibitory effect on digestive enzymes and antioxidant potential of commonly consumed fruits. J. Agric. Food Chem. 62, 4610-4617.

Ranilla, L.G., Kwon, Y.-I., Apostolidis, E., Shetty, K., 2010. Phenolic compounds, antioxidant activity and in vitro inhibitory potential against key enzymes relevant for hyperglycemia and hypertension of commonly used medicinal plants, herbs and spices in Latin America. Bioresour. Technol. 101, 4676-4689.

Rivera, D., Obón, C., 1995. The ethnopharmacology of Madeira and Porto Santo Islands, a review. J. Ethnopharmacol. 46, 73-93.

Séro, L., Sanguinet, L., Blanchard, P., Dang, B.T., Morel, S., Richomme, P., Séraphin, D., Derbré, S., 2013. Tuning a 96-well microtiter plate fluorescence-based assay to identify AGE inhibitors in crude plant extracts. Molecules 18, 14320-14339.

Shai, J.L., Magano, R.S., Lebelo, L.S., Mogale, M.A., 2011. Inhibitory effects of five medicinal plants on rat alpha-glucosidase: comparison with their effects on yeast alpha-glucosidase. J. Med. Plants Res. 5, 2863-2867.

Spínola, V., Llorent-Martínez, E.J., Gouveia-Figueira, S., Castilho, P.C., 2016. Ulex europaeus: from noxious weed to source of valuable isoflavones and flavanones. Ind. Crops Prod. 90, 9-27.

Tadera, K., Minami, Y., Takamatsu, K., Matsuoka, T., 2006. Inhibition of alphaglucosidase and alpha-amylase by flavonoids. J. Nutr. Sci. Vitaminol. (Tokyo) 52, 149-153.

Tsuji-Naito, K., Saeki, H., Hamano, M., 2009. Inhibitory effects of Chrysanthemum species extracts on formation of advanced glycation end products. Food Chem. $116,854-859$.

Villiger, A., Sala, F., Suter, A., Butterweck, V., 2015. In vitro inhibitory potential of Cynara scolymus, Silybum marianum, Taraxacum officinale, and Peumus boldus on key enzymes relevant to metabolic syndrome. Phytomedicine 22, 138-144.

Worsztynowicz, P., Napierała, M., Białas, W., Grajek, W., Olkowicz, M., 2014. Pancreatic $\alpha$-amylase and lipase inhibitory activity of polyphenolic compounds present in the extract of black chokeberry (Aronia melanocarpa L.). Process Biochem. 49, 1457-1463.

Yin, Z., Zhang, W., Feng, F., Zhang, Y., Kang, W., 2014. $\alpha$-Glucosidase inhibitors isolated from medicinal plants. Food Sci. Hum. Wellness 3, 136-174. 